\title{
「丸池復活プランづくりワークショップ」支援の実際
}

\section{Actual Situation of Supporting Activity to the Workshop of Maruike's Renaissance Plan}

\author{
伊藤千恵子* 須藤 哲*
}

CHieko ITO Satoru SUTO

\section{はじめに}

新川丸池公園は, 三鷹市の東南部に位置する面積約 2.1ha の都市公園である。勝㴊神社を取り囲むように梅林 や畑, 雑木林や原っぱ公園, ここは, 都市の中に残された 数少ない自然が感じられる地域である。かって, 仙川の水 源であった丸池は, その後周囲の都市化が進み, 湧水屯少 なくなり, 池の水は污れ，仙川の河床が掘り下げられ，埋 め立てたのは 1969 年であった。その後, そこで遊び育っ た人達から丸池復活を期待する熱い思いが寄せられ，*1 「コミュニティカルテ」を基に市民がつくっだ2「まちづ くりプラン」に丸池復活が提案され, その後三鷹市が策定 した「緑と水の回遊ルート整備計画」(1994 年)に盛り込 まれた。

1997 年,「丸池復活プランづくり」は地域の皆さんによっ て構成された「丸池復活プランづくり運営委員会」(井上 利明委員長）を中心にワークショップ形式で行われた。完 成した「丸池復活プラン」は1997 年11月ワークショップ 参加者の皆さんから三鷹市長に提言され, 翌1998 年に一 期工事区域を対象とした「丸池実施設計ワークショップ」 が行われた。三鷹市は，提言されたプランを基に実施設計 を行い, 1999 年 9 月工事着工, 2000 年 3 月末に完成する 予定である。地域の皆さんから寄せられた「丸池復活」に 対する熱い思いは 10 年余りを経て実現するのは目前だ。

「丸池復活プランブくりワークショップ」の支援組織の 主体である財三鷹市まちづくり公社の立場から熱意あふれ る地域のみなさんによるワークショップの裏側の紹介を行 うと共に, 支援組織の一員として活動した設計者の立場か ら支援体制や進行のあり方などについて整理を行う。

\section{【「財団法人三鷹市まちづくり公社」の立場から}

䁶三鷹市まちづくり公社は，「市民が主体的に行うまち づくりを支援する」目的で，1994 年 4 月 1 日に発足し， 財団法人として東京都から認可を受けたのは 1996 年 4 月 1 日，三鷹市が 100\%出捐する団体である。

\section{1. 丸池復活プランブくりワークショップへの助走}

ワークショップを開催する半年前（1996 年 8 月頃）か ら(1)丸池復活プランブくりワークショップの趣旨, (2)丸池 復活に注目してもらうため, 秋にイベントを開催すること, (3)イベント実行委員会を丸池復活プランづくり運営委員会 の母体にすることなどについて新川中原住区内の町会長・ 自治会長・青少年対策地区委員長等の自宅を戸別訪問し説 明を行った。この戸別訪問によって, ワークショップのス タートにあたって一定の理解を得ることが出来たと考えら れるし，その後の会議の進行をスムーズなむのにした。

そして, 地域の皆さんに丸池復活を知らせるために, 実 行委員会が,「第 1 回丸池わくわくまつり」を開催したの は 1996 年 10 月 26 日であった。丸池わくわくまつりの準 備は, 実行委員が子供班・総務班・歴史班・記録班・模擬 店班・餅つき班等に分かれ，仕事を終えてから夜の打ち合 わせ会に参加し, まつりのアイデアを出し合い, 意見を調 整しながら進められた。すでに協働作業や合意形成の始ま りであった。

初めてのまつりには, 子供から大人まで 1000 人以上が 集まって, 盛大に開催された。このまつりで「丸池復活」 は地域の皆さんに広く認知された。その後, 実行委員会が 母体となって, 井上利明委員長と大木正雄相談役を中心に 「丸池復活プランブくり運営委員会」が組織され, い上い よ,ワークショップが始まったのは1997年 2 月のことだっ た。既に, ワークショップの準備を初めてから 6 ケ月を経 過していた。以来, まつりは年々盛大になり，1999 年開 催の第 4 回では, 2000 人を超える参加者を迎えた。

\section{2. ワークショップの支援組織}

○丸池復活プランブくり運営委員会ニワークショップの 運営 (進め方の確認・参加者の受付・写真撮影・ビデ オ撮影・ニュース編集等)

○(侏生態計画研究所 小河原孝生氏 $=$ アドバーザー（生 物・植物を始め, 生態系全般) 
○(有)大久手計画工房 伊藤雅春氏 $=$ 企画・運営 $($ フ シリテーター・プログラム作成・ワークショップの記 録・ニュースの編集等)

$\bigcirc($ 株)戸田芳樹風景計画 $=$ 立体模型の作成・丸池整備工事 実施設計

○三鷹市都市整備部緑と公園課＝市の立場で参加

○(財)三鷹市まちづくり公社＝ワークショップ全体のコー ディネート

\section{3. 丸池復活プランづくりワークショップ 三つのねらい} 三鷹市まちづくり公社は，丸池復活プランづくりワーク ショップのコーディネートを行うにあたり, 三つのねらい を持っていた。

（1）すばらしいプランをつくること

この地域の生態系に考慮したすばらしいプランを作るこ と。そのため小河原孝生氏にアドバイザーとして参加して いただき, ワークショップの中でミ二講座を開き, 池と生物・ 植物との関係など生態系の知識を参加者が学ぶ機会を持て るように進めた。参加者が色画用紙等を使って手作りした $6 つ の$ 立体模型をひとつにまとめ，この地域の生態系に配 慮し, 参加者の希望を取り入れたプランを作っていただい たのは，(株戸田芳樹風景計画のスタッフの皆さんである。

（2）ワークショップに参加した人々が新たなコミュニティ をつくること

ワークショップは, 毎回ティータイムを設け，お茶とお 菓子を用意した。お菓子を食べながら，参加者同士が顔見 知りになり，おしゃべりがはずみ，情報を共有したり，楽 しい雾囲気づくりに配慮し，新しいコミュニティができる ように努めた。また，ひとつの課題に対し充分な意見交換 ができるように，プログラムの進行にはゆとりを持たせた。 （３）ワークショップに参加した人々が自治を担う市民に なること

このワークショップの経験を通して参加者の皆さんが 「自分たちのまちは自分たちでつくる」と，市民が主体的 にまちづくりを実践するようになったら，どんなにすばら しいかと夢を見ながら、ワークショップのコーディネート を行ってきた。地域の皆さんを中心に，運営委員会を組織
していただき，ワークショップの運営に主体的にかかわっ ていただいた。運営委員会の皆さんには, 会場の設営, 参 加者の受付, 資料配布, 参加者の誘導, 茶菓の用意, 写真・ ビデオ撮影, 広報誌「丸池よみがえる」の編集・発行を初 め, ワークショップを盛り上げ, 丸池復活が地域に認知さ れるよう様々な工夫も行っていただいた。

そして，まちづくり公社の重要な役割は，このワークショッ プが楽しくスムーズに運営され，地域の皆さんに親しまれ， 大切にされる公園プランができあがり, 新しいコミュニティ が作られ，完成したプランがこの地域の皆さんに広く認知 されることだと認識していた。

完成したプランが，「特定の人々によって作ったもの」 と思われるようであっては失敗に終わってしまう。そのた めには，(1)公園隣接住民の参加を得ること，(2)多くの方に 参加していただくように，毎回電話による参加の呼びかけ を行ったこと，(3)毎回のワークショップの内容をニュース にして約 2000 部を地域に配布し，参加しなかった方にあ 情報の提供をしてきた。運営委員会の皆さんの呼びかけむ あって，参加者は，延べ 1000 人以上となった。

\section{4. 前提条件の提示}

ワークショップをスムーズに進めるために，目的や計画 づくりを進める上で次の前提条件を共有した。

(1)相互の役割分担の明確化

(2)三鷹市が整備工事を必ず実施する予定であること

(3)全体のスケジュールの確認

(4)道路を含めた周辺整備計画の内容

(5)プランづくりに反映できること，できないこと

\section{5. 情報の公開と共有}

ワークショップで参加者・専門家・行政が共通の土俵に 立つためには，情報の共有が必要であり，情報公開は徹底 して行わなければならない。(1)プランづくりの対象面積, (2)土地の所有形態, (3)丸池の里の全体構想, (4)地質等を始 め新たに発生した情報も，タイムリーに提供し共有した。

丸池復活プランづくりワークショップは, 運営委員会の 主体的な運営, 伊藤雅春氏によるすばらしい進行，いつも

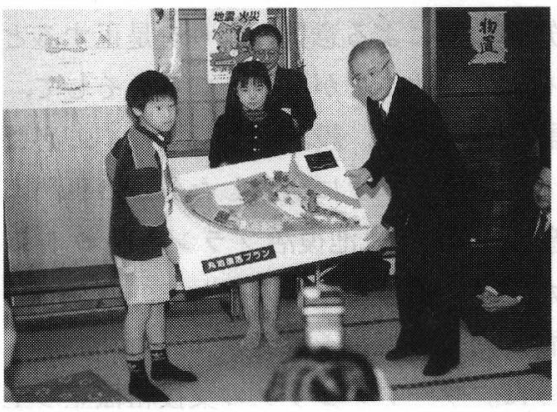

○市長への提言

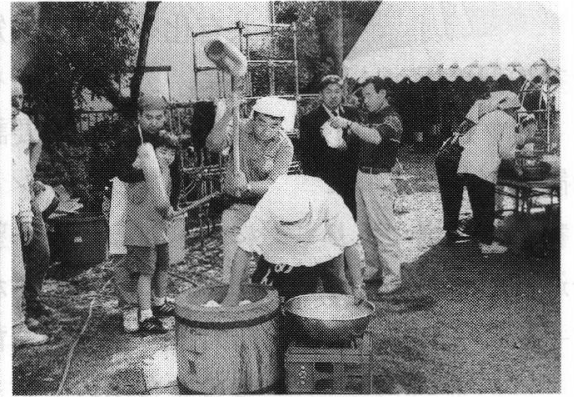

○第一回丸池わくわくまつり

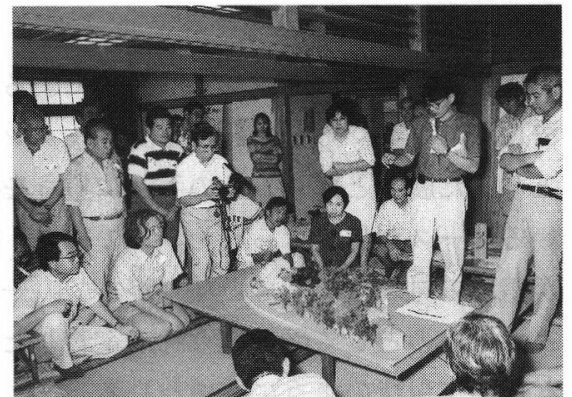

○ワークショップの風景 
適切なアドバイスをくださる小河原孝生氏，環境に配慮し た設計者の戸田芳樹風景計画，行政職員のスタッフにより 進められた。ワークショップの準備段階では, 伊藤雅春氏 との納得いくまでの激しい議論は時に深夜にも及ぶこと屯 あった。毎回，会議の事前打ち合わせに，井上利明委員長 のご自宅まで同ってご相談させていただいた。1 年間に約 30 回の運営委員会を開催したので，事前打ち合わせも同 じ回数になる。そして, 各ワークショップ開催前に, 運営 委員会会議を開き，プログラムの説明と質疑，役割分担の 確認を行った。会議では，全員の合意を得ながら，プログ ラムの変更む行った。こうして細部に渡る打ち合わせが行 われワークショップは開催された。

\section{ロ設計者の立場から}

市長への提言前後, 「丸池復活プランづくり」が全国紙 ばかりか数多くの地方紙でも取り上げられ，紙面をにぎわ せたことは記憶に新しい。各紙とも，表現の差はあるもの の，ワークショップが地域住民の代表者によって運営され ていることと，参加者の意見が色濃く反映された計画であ ることが中心の記事となっていた。これは，参加型の場つ くりを越えた「市民主体のまちづくりが」注目されたこと に他ならない。

ワークショップ形式による参加型の場づくりの成功の鍵 は，第一に参加者の意識の高さに左右される。丸池復活プ ランづくりでは, 丸池の復活が市民の強い希望であり，公 園づくりへの合意がすでにあったこと，ワークショップの 運営を地域住民の代表者が主体となって行ったこと，さら に，この井上委員長を中心とした運営委員会の下地となる 地域のコミュニティがある程度成熟していたことが大きな 要因となった。そして，市民主体のプランづくりを支援す る体制と手法の充実が第二の鍵となり，(財)三鷹市まちづく り公社を中心とした支援組織がこれに当たった。

ここでは，まちづくり公社とともにワークショップの支 援スタッフの一員として参加した設計者の立場から，他地 区にも応用可能な骨格的要素となる事業の目標設定，支援 組織の構成之役割分担のあり方, 参加型の場づくりの今後 の展望などについて整理を行う。

\section{1. 事業の目標設定}

これまでのワークショップ形式による参加型の場づくり では，あのづくりを主題とし，ワークショップ自体が目的 となった展開となり，その手法に重きを置きがちになって いるケースが見受けられた。この結果，参加型の場づくり が着地の見えないものとなりがちで，一過性のイベントの ようなものとして受け取られ，定着した手法になり得てい ないのが現状のようにに思われる。

「丸池復活プランづくり」ではワークショップは選択肢
の一つであり，この形式を選択する際の前提となった目標 設定があった。「ワークショップの三つのねらい」につい ては前文で紹介したとおりであるが，地域住民主体の風景 作りを念頭に，参加者が生活の場の一部として将来的にも 関わりを持ち続けられる下地づくりを目的とした目標設定 であった。ワークショップ形式の採用だけでなく，支援組 織のメンバー構成やワークショップの進行なよ゙全てがこの 目標に基づいて設定されている。そして，この目標がワー クショップ進行のプログラム立案や，各回のワークショッ プの振り返りなどの細部にわたる道しるべとなっていた。

参加型の場づくりの支援組織立ち上げと運営に当たって は，これらを念頭に置いた各地区個別の事情を反映した目 標設定を行うことが重要なポイントとなる。

\section{2. 支援組織の役割分担}

ワークショップの支援組織の構成は先に示したとおり, 公 社とワークショップのプログラム立案や進行役であるファシ リテーターの他に, 専門家を加えた体制であること,そして 各々の役割分担が明確であったことが大きな特色となって いる。これは, ワークショップの放らいのひとつである[す ばらしいプランをつくること〕を念頭に置いた体制であった。 （1）ファシリテーターと専門家

ファシリテーターは, ワークショップの進行役として不 可欠な存在であり，個人の意見を交えることなく参加者の 意見をまとめ上げることが求められる。また，公園づくり やまちづくりでは，計画・設計などの専門的な知識をもっ た技術者の意見が必要とされる場面が多く発生する。一方 ファシリテーターは，日常業務に打いて計画・設計に携わっ ている場合も多く，時として二つの役割を兼務する場合が ある。ここで注意が必要なことは，二つの役割を兼務した 場合, 中立的な立場でありながら個人の意見を述べなけれ ばならない局面があり, 結果, 参加者の混乱をま权き, 円 滑な進行に支障をきたすおそれがあることである。参加者 のワークショップに対する経験や知識の度合いにもよるが, 基本的にはファシリテーターと専門家は役割分担を明確に することが望ましい。

（2）必要に応じた専門家の参加

ワークショップヘの専門家の参加は参加者の専門知識の 共有化を促進し，知識の差による意見の偏りを是正すると 共に, 公平な判断を導き出すことが可能となる。そして, 専門家に参加を要請する場合は, 設計者だけでなく, 必要 に応じてワークショップのテーマに合致した分野の専門家 に要請することが望ましい。「丸池復活プランづくり」は かっての丸池復活が主題となっている。そして, 人々が望 む丸池は，地域で育った大人達が子供の頃に見た，いきむ ののすむ水辺であった。ワークショップの支援組織立ち上 げの際にはこの主題を受け，いきものやその生息環境に関 
する専門知識をあった生態プランナーに参加が要請された。

そして, 専門家はその知識の伝達だけではなく, 支援組 織の一員としてワークショップの主題や目標をよく理解し たうえで, 適切でわかりやすい説明や，参加者の興味を引 き出す学習の場の提供を心掛けることが求められる。

(3) 横断的な行政の支援

2 ヶ年を通じ，公園の実施設計と工事の事業主体である 三鷹市緑と公園課が，全てのワークショップに参加した。 そして, 対象地の概要, 土地の所有, 事業スケジュールや 進渉など，ワークショップの進行とあわせた，行政側から の詳細な情報提供を行った。隣接道路の扱いについても関 係部署が出席して, ワークショップに反映できることとで きないことの確認と伝達を行った。このように, 関係各署 の横断的な支援が不可欠であることはいうまであない。

\section{3. ワークショップの進行}

参加者が気軽に，そして継続的にワークショップに参加 できるためには, 毎回の進行を決定するプログラムやッー ルの充実はもとより, これらを設定するに当たっての, 事 前の準備と参加を促す広報活動が重要となる。

(1) 事前の準備

ワークショップでは, 毎回おおむね次の流れで準備と綿 密な打ち合わせが行われた。(1)公社とファシリテー夕によ る大枠のプログラム立案。(2)専門家を交えた具体的メニュー 設定とッールの準備。(3)運営委員会と合同のシュミレーショ ンとプログラム修正。(4)本番ワークショップ。(5)運営委員 会と支援組織によるワークショップの振り返り。

このような何段階かの工程に参加者の代表が参加し意見 を述べることによって, 相互の意志の疎通が高まり, 内容 の濃いワークショップ進行が可能となった。

（2）広報活動

より多くの人たちの参加を促し, 内容を認知してもらう ために, ワークショップ開催に先駆けて公社が発行した 「ワークショップのお知らせ」と, ワークショップ後に発 行した「ワークショップニュース」が地域に配布された。 また, 運営委員会が主体となって編集・発行した情報誌 「丸池よみがえる」が同時に配布されたことは, 市民の視 点で報告される内容が読者に直接伝わり, 大きな役割を担っ ていた。

\section{4. 参加型の場づくりの展望}

参加型の場づくりの着地点は, ワークショップの円満な 終焉でも, 工事の完成でもない。参加型の場づくりを通じ た参加者同士のコミュニティの醸成や，行政と市民の相互 理解がいかに図れたかはあとより, 完成した場を通じてこ の関係を継続しつつ, 市民がその場にどう関わり続けるか が重要なポイントとなろう。新川丸池公園の事業では, 2
年に渡るワークショップを経て, 今後も何等かの形で公園 との関わりを持ち続けたいとの声が大きくなっていると聞 いた。参加型の場づくりの先に見える「市民主体のまちづ くり」の芽生えに期待して，活動の今後を見守りたい。

\section{おわりに}

ここに感激して伝えたいことがある。それは丸池公園に 隣接する「杏林大学看護婦寮跡地ワークショップ」が丸池 復活プランづくり運営委員会のコーディネートで, 今年 1 月 15 日から始まったことである。市民が主体的にワーク ショップの進め方を考え, プログラムをつくり, 進行屯行っ ている。プロのファシリテーターもアドバイザーもなく, 地域の皆さんの知恵と協力により, ワークショップが始まっ た。第 1 回のワークショップでは,「落ち葉・枝打ち・堆 肥から炭焼へ」と,『リサイクル型公園』にしたいという 声が出たとのこと。今後のワークショップの行方が楽しみ である。「行政にお願いするばかりではなく, 自分達でで きることは, 自分達でやろう」との発意の表れを感じる。 丸池復活を目前にし，この地域で『市民主体のまちづくり の胎動』を感じ, 痛く感動している。

最後に, 丸池復活プランづくり運営委員会の皆さんに心 から，エールを送りたい。

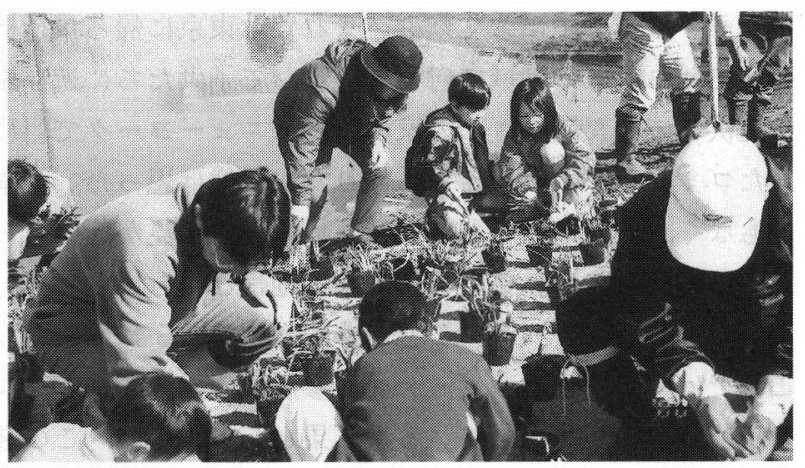

○工事中には参加者で水草の植え付けが行われた。

\section{$※ 1 「 コ ミ ュ ニ テ ィ カ ル テ 」($ 昭和 55 年〜平成元年)}

三鷹市内 7 つのコミュニティ住区単位に市民が地域 診断をし，まちづくりに対する要望をまとめたもの ※2「まちづくりプラン」(平成元年)

コミュニティカルテを基に，1991 年（平成 3 年以 降）の三鷹市の基本構想，基本計画に反映させる目的 でまちの整備イメージを市民がまとめたもの

\section{参考文献}

1)「丸池復活プランブくりワークショップの記録」: 丸池復活プ ランづくり委員会・財団法人三鷹市まちづくり公社（平成 9 年 11 月発行・平成 11 年 4 月改訂)

2 ）「市民参加による生物多様性回復手法の開発に関する調査業 務報告書」：建設省土木研究所緑化生態研究室・(社) 日本 環境教育フォーラム（平成 11 年 3 月） 